\title{
Cognitive Learning Outcomes: Its Relationship with Communication Skills and Collaboration Skills through Digital Mind Maps-Integrated PBL
}

\author{
Nurkhairo Hidayati, Siti Zubaidah, Endang Suarsini, and Henry Praherdhiono
}

\begin{abstract}
This study aimed to investigate the relation of communication skills and collaborative skills simultaneously on student cognitive learning outcomes using the Digital Mind Maps-Integrated PBL model. This correlational study was conducted on biology education students at Universitas Islam Riau, Indonesia. The research instrument consisted of observation sheets to assess communication and collaboration skills, as well as essay tests to measure cognitive learning outcomes. Data analysis used multiple regression analysis. The results showed a significant relationship between communication skills and collaboration skills on cognitive learning outcomes with $F$ count $(13.966)$ and $p$-value of $0,000<\alpha$ (0.05). Besides, these two variables simultaneously also contributed to the achievement of student learning outcomes with an Effective Contribution (EC) value of $46.61 \%$. Thus it can be concluded that the improvement of communication skills and collaboration skills have a contribution to the learning outcomes obtained by students. Therefore, educators can empower both of these skills so that students' cognitive learning outcomes also improve.
\end{abstract}

Index Terms - Communication, collaboration skill, cognitive learning outcomes, digital mind maps.

\section{INTRODUCTION}

Communication is an essential component needed by humans to adapt to the environment and is one of the crucial elements for establishing interpersonal relationships [1]. Communication can allow humans to express concepts and ideas in their minds. Besides, communication can also influence others so that success can be achieved through good communication [2]. The effective use of communication skills is an important interpersonal competency so that it becomes one of the skills needed in the 21st century [3]. Interpersonal competence involves developing communication skills. Not everyone has good communication skills, so the important role of these communication skills needs to be empowered and trained [4]. Empowerment of these skills can be carried out in various fields including education because effective communication skills play an important role in building student character [5]

Manuscript received September 10, 2019; revised April 1, 2020. This work was supported in part by Universitas Islam Riau and Universitas Negeri Malang, Indonesia.

Nurkhairo Hidayati is Universitas Islam Riau, Indonesia (e-mail: khairobio@edu.uir.ac.id).

Siti Zubaidah and Endang Suarsini are with Universitas Negeri Malang, Indonesia (e-mail: $\quad$ siti.zubaidah.fmipa@um.ac.id, endang.suarsini.fmipa@um.ac.id).

Henry Praherdhiono is with Universitas Negeri Malang, Indonesia (e-mail: henry.praherdhiono.fip@um.ac.id) and preparing students for various job opportunities [6].

Communication skill are the ability to interact with verbal and non-verbal messages by listening and reacting efficiently [7], [8], involving the delivery of ideas, messages, and information to influence someone's behavior or persuade them [9]. Communication skills can also be interpreted as the process of delivering information and using listening skills effectively and showing openness to the ideas and thoughts of others [10]. Communication skills require the ability to understand what others are saying and be aware of the source of communication [11]. Effective communication is influenced by various elements that must work together in harmony. These elements include the sender of the message, the recipient or listener, the message, the media, feedback, and the purpose of communication [12], [13] so as not to cause differences in perception and hinder the success of communication [8]. Communication includes four primary skills, namely speaking, listening, investigating, and observing [6].

Students who have good communication skills can achieve better learning outcomes [14]. This connection occurs because someone with good communication skills has adequate knowledge of the information to be conveyed and can receive information well. Mastering this information ultimately helps achieve better learning outcomes [15]. In addition, communication is a vital component to motivate students who in turn can help them take action and achieve the goals set at the beginning of learning [10]. Communication skills can help convey messages in clearer and better easier to understand ways so students can understand the material being studied. Understanding of this material contributes to the achievement of cognitive learning outcomes [16]. Even Fashiku [12] explains that a lack of readiness for learning does not cause the academic failure of students, but because the communication that takes place is not effective.

Communication skills are closely related to other skills,for example, collaboration skills [8]. When collaboration occurs between people, communication skills are needed for the collaboration to take place. In other words, communication skills become the basis for collaboration skills. During collaborative activities, communication has the role of bringing implicit thinking towards explicit explanation [17]. Communication and collaboration are about fostering effective communication and engaging with others in group relationships [18].

Collaborative skills are the ability to work in teams by joining several individuals together to achieve common goals 
[19], [20] by supporting the work of other team members [21]. In collaboration, there is interaction among group members. Members of this group consist of individuals with different characteristics so that they can share their experiences and information [22], [23]. Several ways have been proven effective in teaching the principles of collaboration in the classroom, including constructing knowledge, establishing group agreements, determining the stages of division of work and accountability for tasks [24].

Various important roles of collaboration skills can be found not only during the learning process but also when students are in a work environment. Van Laar, Van Deursen, van Dijk, \& de Haan [3] in their writings explained that collaboration skills are an important part of 21st-century skills, especially for workers because collaboration skills require teamwork. Teamwork plays a role in team integration so that each team member can share ideas and knowledge into learning experiences [23], [25]. Another benefit of collaboration skills is improving students' social competence and learning effectiveness [26] to produce better performance [27].

Cognitive learning outcomes can be linked to collaboration skills. During the collaboration, there is social interaction among students in the group. It stimulates the elaboration of conceptual knowledge because in groups, of students try to make themselves understood and able to understand other group members [24] so that construction of shared knowledge [18]. The research found that active participation of students during collaboration in groups can help them complete the tasks better than individual work [28] Other research also explains that students who work collaboratively can express ideas better [29] and improve learning outcomes [30]. Conversely, the lack of collaboration skills hinders the performance of students in groups so that it influences learning outcomes [31].

The relationship between collaboration skills and cognitive learning outcomes has been done as described in the previous paragraph [15], [18], [31]. Likewise, the relationship between communication skills and cognitive learning outcomes has also been widely explained in various study [10], [14], [15]. However, studies that examine the relationship between the two skills together on cognitive learning outcomes so far are still rarely conducted. To find out the relationship between communication skills and collaboration skills, these two skills need to be empowered in the classroom by using appropriate learning strategies.

The development of communication skills and collaboration skills is a long-term effort, but educational institutions such as university can take a role through implementing active learning processes. The active learning process involves students in each stage of learning so that the learning experience takes precedence [32]. This learning experience is obtained through students' activities in searching for information, discussing up to making decisions and conclusions [33] so that they can practice communication and collaboration skills.

Various learning strategies facilitating communication and collaboration skills in the classroom have been suggested in the field of education [34]. For example, research conducted by Martyn, Terwijn, Kek, \& Huijser [35] that Problem Based
Learning (PBL) helps students explore information to improve communication and collaboration skills. PBL also directs students to work collaboratively to find solutions [36]. Other studies using mind map-oriented sharing approaches enable students to learn to collaborate. Mind maps that are made digitally or known as Digital Mind Maps (DMM) can be shared among friends [37] and develop various lifelong skills including communication skills, teamwork, critical analysis, and planning work [38]. The use of mind maps also helps in preparing presentations so that the information to be communicated becomes easier to understand [39]. Therefore in this study, DMM is integrated with PBL, which is then abbreviated to DMM-Integrated PBL model.

The integration of DMM and PBL was done because in PBL students are presented with tasks in the form of problems. When students are presented with assignments in the form of problems, they rarely try to do the right brainstorming of the problem before trying to solve the problem [40]. This activation of prior knowledge helps students by simulating the links between new and old information. Integration PBL with mind maps in this study because mind maps can act as a mediator in connecting between one concept and another, visualizing prior knowledge in the form of broad concepts and add new detailed information [41], and assist in summarizing PBL discussions and enabling reflection [42].

Referring to the explanation in this introduction, a study is needed to reveal the relationship between communication and collaboration skills on cognitive learning outcomes using the DMM-Integrated PBL learning model. The potential possessed by this learning model can improve communication and collaboration skills. Through these multiple correlation studies, the contribution of each variable can be expressed in cognitive learning outcomes. Even the simultaneous contribution of the two variables can also be seen in cognitive learning outcomes.

\section{METHODS}

\section{A. Research Design}

The research done multiple correlational study to reveal the contribution of communication skills and collaboration skills to the cognitive learning outcomes of students by using the DMM-Integrated PBL model. The learning process began with the activities of students preparing DMM. Making DMM can help students connect the material learned with the concepts they have learned before. In the classroom, before orienting students to the problem, the lecturer asked questions related to the DMM that students had made. After students made a problem statement, the next step is to search for references to answer the problem. The result of search references are written in reports and communicated through class presentations and discussions. Responses from various groups could enrich the solution to the problems that had been found. In the final section, evaluation and reflection was carried out on the learning process that has been carried out.

\section{B. Instrument}

The instrument for measuring communication and 
collaboration skills was observation sheets. This assessment rubric used a Likert scale with four answer choices which are very good, good, enough, and not good. The measured communication aspects were speaking, writing, listening, and nonverbal. The collaboration aspect consists of responsibility, respect, contribution, organize work, and work as a whole team. The instrument for measuring cognitive learning outcomes in an essay test based on bloom taxonomy. Before being used in data collection, all instruments were validated. The results of expert validation showed the validation value of communication and collaboration instruments were 3.83 (valid). The validation test of the cognitive learning achievement test results using the Pearson product moment test showed that all items in the instrument were valid and the reliability test results were 0.872 (reliable).

\section{Data Collection and Analysis}

Data collection of communication skills and collaboration skills was done by doing the observation during the learning process. Observations made are based on the assessment rubric provided. Observer scores according to the activities of students. Learning outcomes data were collected through essay tests given to students. Furthermore, a score was given for each answer to the questions that had been done by students. All research data were first tested for normality using KolmogorovSmirnov. The results of this normality test showed a pvalue of $0.200>\alpha$ which means that the research data was normally distributed. Furthermore, the research data were analyzed using multiple regression analysis to test the correlation of predictors and criteria.

\section{RESULTS AND FINDINGS}

This study used communication skills and collaboration skills as predictors to determine their relationship with cognitive learning outcomes as criteria. The initial step of the researchers used the Anova test. ANOVA test aimed at determining determine whether the predictor significantly has a relationship with the criteria or not. ANOVA test results can be seen in Table I.

TABLE I: THE ANOVA OF THE CORRELATION BETWEEN COMMUNICATION AND COLLABORATION SKILLS ON COGNITIVE LEARNING OUTCOME WITHIN

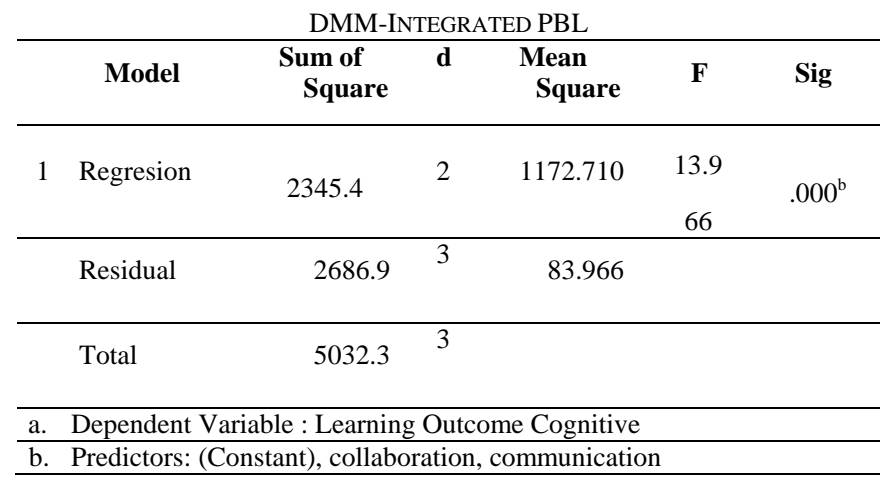

Table I showed the calculated F value obtained was 13.966 with a p-value of $0,000<\alpha(0.05)$. This number gives the meaning that communication skills, together with collaboration skills, can significantly predict student cognitive learning outcomes.
After seeing the ANOVA test results, it is continued by knowing the coefficient of multiple correlation as shown in Table II. Table II summarizes the results related to the presence or absence of the relationship of all predictors with criteria. The regression equation obtained is $\mathrm{Y}=-11.671+$ $0.341 \mathrm{X} 1+0.471 \mathrm{X} 2$.

TABLE II: THE REGRESSION COEFFICIENT OF THE CORRELATION BETWEEN COMMUNICATION AND COLLABORATION ON COGNITIVE LEARNING OUTCOMES WITHIN THE DMM-INTEGRATED PBL Model Summary

\begin{tabular}{lcccc}
\hline Model & $\mathbf{R}$ & R square & $\begin{array}{c}\text { Adjusted R } \\
\text { Square }\end{array}$ & $\begin{array}{c}\text { St Err of the } \\
\text { Estim }\end{array}$ \\
1 & $.683^{\mathrm{a}}$ & .466 & .433 & 9.16330 \\
\hline Predictors: (Constant), collaboration, communication &
\end{tabular}

Predictors: (Constant), collaboration, communication

Dependent Variable : Learning Outcome Cognitive

Referring to Table II, the value of $\mathrm{R}$ obtained was 0.683 , while R2 was 0.466 . Thus this table provides information that communication skills and collaboration skills together contribute $46.61 \%$ in achieving cognitive learning outcomes of students, while the remaining $53.4 \%$ is explained by other variables outside this study. The contribution of each predictor variable to the criterion variable can be seen in Table III.

TABLE III: CONTRIBUTION OF COMMUNICATION AND COLLABORATION SCORES ON COGNITIVE LEARNING OUTCOMES

\begin{tabular}{lcc}
\hline \multicolumn{1}{c}{ Variable } & EC & RC \\
\hline Communication Skill & $17.67 \%$ & $37.90 \%$ \\
Collaboration Skiill & $28.94 \%$ & $62.10 \%$ \\
Communication \& & $46.61 \%$ & $100.00 \%$ \\
Collaboration & & \\
\hline
\end{tabular}

Table III provides information that collaboration skills make a greater contribution than communication skills in determining the achievement of students' cognitive learning outcomes. The contribution of collaboration skills to cognitive learning outcomes is $62.10 \%$ while communication skills contribute to 37.90 .

\section{DISCUSSION}

Communication skills and collaboration skills can be used to predict the achievement of students' cognitive learning outcomes. The results of this study indicate these two variables contributed $46.6 \%$ to cognitive learning outcomes. Communication and collaboration skills are important skills needed by students in their social environment. Both of these skills during the learning process are empowered through the DMM-Integrated PBL learning model. The implementation of the DMMIntegrated PBL Model places students in group learning situations and has discussions to solve problems and utilize DMM. The results of research by Liyaghatdar, Abedi, Jafari, Bahrami [43] found that the learning process carried out with discussion was more effective in improving communication skills and learning outcomes. Furthermore, this learning model also helps students in constructing knowledge. Various concepts and knowledge that were read 
when compiling the DMM were shared with other members through discussions. In particular, if group members find different information or ideas, there are more opportunities for discussion. Exposure to different points of view results in increased knowledge, thereby increasing learning outcomes [44].

Previous research done proves that there is a correlation between communication skills and student learning outcomes because communication skills are inseparable from the understanding and level of knowledge of the transmitter and receiver of information. In other words, the better a person's communication skills are, the better their knowledge and the learning outcomes achieved will also be better [14]. In addition, when conducting discussions to solve problems, students try to understand the information better communicated by their peers. For example, by summarizing, examining, and trying to imagine perspectives from points of view that conflict with their points of view so that the right conclusions are reached [34].

Communication skills bring the learning situation to a better understanding because communication skills are related to the ability to transfer information and negotiate to mean. When students want to convey information, they must ensure that the information can be well received by the listener. Therefore, the readiness of students in communication is also determined by the level of understanding of the content or learning material. One of the criteria for someone with good communication skills is to show a comprehensive understanding of the topic presented [45]. The importance of mastering content is also explained by Staniforth [46] that mastering content at the time of communication affects the interaction between the transmitter and receiver of the message.

In addition to communication skills, collaboration skills also correlate with the achievement of cognitive learning outcomes. Even the results of the analysis show the contribution of collaboration skills is more significant than communication skills on student cognitive learning outcomes. The contribution of collaboration skills to the achievement of learning outcomes because collaboration activities enable students to be actively involved in the learning process, especially in problem solving. During the collaboration, students are responsible for completing assignments and various knowledge they have. This is in line with research conducted by Brindley, Walti, \& Blaschke that at the time of collaboration, students share their knowledge so that they obtain richer knowledge through joint exploration and the achievement of shared meanings [47]. Other research results also show that collaborative activities make students more involved in the learning process so that it leads to increased mastery of concepts [48], [49].

Collaboration allows groups to make better decisions than each individual does its posibility to consider various perspectives. In the educational environment, many studies have been directed at collaboration. This research mainly focuses on the use of collaboration to optimize learning outcomes [50]-[52]. Collaboration in groups provides an opportunity to work constructively with peers and enrich knowledge and understanding by explaining concepts to others so that learning outcomes are also better [53]. In addition, during collaboration, there is an interaction between peers. This interaction encourages cognitive conflict by uncovering differences in knowledge between one another, thereby increasing students' understanding of a concept. An important aspect of collaborative activity is the negotiation of conflicting points of view [54].

The contribution of collaboration skills to learning outcomes is inseparable from the learning model used. As in this study, using the DMM-Integrated PBL model facilitates students working in groups. Various benefits are obtained when students work in groups. For example, they support each other when experiencing problems, share information, and find solutions together. In groups, students need to solve problems, deal positively with conflicts that might arise, and reach an agreement [18]. Besides, the DMM-Integrated PBL model also provides students the opportunity to reflect on the final stages of learning. This reflection is one process to improve collaboration skills as it can equate different perceptions through respecting the opinions of others [55].

To end the explanation in this section, we exclaimed that the achievement of students' cognitive learning outcomes can be done not only by using learning models focusing on final results but can also using learning models that improve communication skills and collaboration skills. It occurs because both skills have been proven to have the contribution to cognitive learning outcomes simultaneously. Students with good communication and collaboration skills are expected to have more significant opportunities to actualize themselves in various fields.

\section{CONCLUSION}

Based on the results of the study, it can be concluded that there is a significant relationship between students' communication skills and collaboration skills with cognitive learning outcomes of students using the DMM- Integrated PBL model. It occurs because communication skills and collaboration skills contribute to the achievement of cognitive learning outcomes simultaneously. However further exploration indicates that collaboration skills contribute more on cognitive learning outcomes than communication skills. The findings of this study are expected to provide direction for further research to utilize the variable communication skills and collaboration skills as predictors for other criteria besides cognitive learning outcomes.

\section{CONFLICT OF INTEREST}

We certify that there is no actual or potential conflict of interest in relation to this article.

\section{AUTHOR CONTRIBUTIONS}

Hidayati formulates of overarching research goals and aims, development or design of methodology, presentation of the published work. Zubaidah plays a role in oversight and leadership responsibility for the research activity and commentary manuscript. Suarsini contributed specifically critical review, commentary manuscript and verification. Praherdhiono participate in revising manuscript critically for important intellectual content. 


\section{ACKNOWLEDGEMENTS}

This research was supported by the Educational Fund Management Institution (LPDP), the Ministry of Finance of Indonesia with number FR2712018124893.

\section{REFERENCES}

[1] A. Erozkan, "The effect of communication skills and interpersonal problem solving skills on social self-efficacy," Educational Sciences: Theory \& Practice, vol. 13, no. 2, pp. 739-745, 2013.

[2] N. Caliskan, "Sinif ogretmenlerinin sozel olmayan iletisim davranislarinin degerlendirilmesi," Master Thesis, Ataturk University, Erzurum, 2003.

[3] J. Haan et al., "Determinants of 21st-century digital skills: A large scale survey among working professionals," Computers in Human Behavior, 2019.

[4] K. Kechagias, "Teaching and assessing soft skills," Thessaloniki, Greece: 1st Second Chance School of Thessaloniki (Neapolis), 2011.

[5] M. D. Rawat, "Importance of communication in teaching learning process Ms Deepti Rawat Research Scholar Shobhit University Meerut," Scholarly Research Journal for Interdisiplinary Studies, vol. 4, no. 26, pp. 3058-3063, 2015.

[6] S. Johnson, "A framework to embed communication skills across the curriculum: A design-based research approach," vol. 12, no. 4, pp. $1-14,2015$.

[7] Z. Asrar, "The impact of communication between teachers and students: A case study of the Faculty of Management Sciences University of Karachi, Pakistan," European Scientific Journal, vol. 14, no. 16, pp. 32-39, 2018.

[8] H. Z. Matin and A. Hamidizadeh, "Relationship between interpersonal communication skills and organizational commitment, (Case study: Jahad Keshavarzi and University of Qom, Iran)," European Journal of Social Sciences, vol. 13, no. 3, pp. 1-2, 2010.

[9] R. N. Osakwe, "Dimensions of communication as predictors of effective classroom interaction," Stud Home Comm Sci, vol. 3, no. 1, pp $57-61,2009$.

[10] M. C. Quieng et al., "21st centurybased soft skills: Spotlight on non-cognitive skills in a cognitiveladen dentistry program," European Journal of Contemporary Education, vol. 11, no. 1, pp. 72-81, 2015.

[11] N. A. Marzuki, C. S. Mustaffa, and Z. M. Saad, "Emotional intelligenc: Its relationship with communication and information technology skills," Asian Social Science, vol. 11, no. 15, pp. 267-274, 2015.

[12] C. O. Fashiku, "Effective communication: Any role in classroom teaching - Learning process in Nigerian schools?" Bulgarian Journal of Science and Education Policy, vol. 11, no. 1, pp. 171-187, 2017.

[13] H. Ozkan et al., "Examining the relationship between the communication skills and self-efficacy levels of physical education teacher candidates," Procedia - Social and Behavioral Sciences, vol. 152, pp. 440-445, 2014.

[14] G. R. Sharifirad et al., "Knowledge, attitude and performance of academic members regarding effective communication skills in education," Journal of Education and Health Promotion, pp. 8-13, 2012.

[15] L. Bakic-Tomic et al., "Elements of teacher communication competence: An examination of skills and knowledge to communicate," International Journal of Research in Education and Science, vol. 1, no. 2, pp. 157-166, 2015.

[16] A. Khan et al., "Communication skills of a teacher and its role in the development of the students' academic success," Journal of Education and Practice, vol. 8, no. 1, pp. 18-21, 2017.

[17] N. M. Webb, "The teacher's role in promoting collaborative dialogue in the classroom," British Journal of Educational Psychology, vol. 79, pp. $1-28,2009$.

[18] H. Le et al., "Collaborative learning practices: Teacher and student perceived obstacles to effective student collaboration," Cambridge Journal of Education, vol. 48, no. 1, pp. 103-122, 2017.

[19] P. Mishra and K. Kereluik, "What 21st century learning? A review and a synthesis," in Proc. Society for Information Technology \& Teacher Education International Conference 2011, pp. 3301-3312, 2011.

[20] A. Sahin et al., "STEM related afterschool program activities and associated outcomes on student learning," Educational Sciences: Theory and Practice, vol. 14, no. 1, pp. 309-322, 2014.

[21] A. J. A. M. Deursen et al., "Internet skills, support sources and beneficial Internet use," International Journal of Human-Computer Interaction, vol. 30, no. 4, pp. 278-290, 2014.
[22] Y. J. Kang et al., "A psychological empowerment approach to online knowledge sharing," Computers in Human Behavior, vol. 74, pp. 175-187, 2017.

[23] K. Vangrieken et al., "Teacher collaboration: A systematic review," Educational Research Review, vol. 15, pp. 17-40, 2015.

[24] E. R. Lai, "Collaboration: A literature review," Research Report, 2011.

[25] K. Plant et al., "Preparing work-ready graduates — Skills development lessons learnt from internal audit practice," Journal of Accounting Education, 2019

[26] R. O'Leary et al., "The skill set of the successful collaborator," Public Administration Review, vol. 72, no. s1, pp. S70-S83, 2012.

[27] V. U. Druskat and D. C. Kayes, "Learning versus performance in short-term project teams," Small Group Research, vol. 31, no. 3, pp. $328-353,2000$.

[28] I. Elgort et al., "Is wiki an effective platform for group course work?" Australasian Journal of Educational Technology, vol. 24, no. 2, pp. 195-210, 2008.

[29] B. Kramarski and Z. R. Mevarech, "Enhancing mathematical reasoning in the classroom: The effects of cooperative learning and metacognitive training," American Educational Research Journal, vol. 40, no. 1, pp. 281-310, 2003.

[30] D. Kuhn and D. Dean, "A bridge between cognitive psychology and educational practice," Theory into Practice, vol. 43, no. 4, pp. 268-273, (2004).

[31] V. Popov et al., "Multicultural student group work in higher education," International Journal of Intercultural Relations, vol. 36, pp. 302-317, 2012.

[32] K. Kim et al., "Effects of active learning on enhancing student critical thinking in an undergraduate general science course," Innovative Higher Education, vol. 38, no. 3, pp. 223-235, 2013.

[33] Y. Chung et al., "Enhancing students' communication skills in the science classroom through socioscientific issues," International Journal of Science and Mathematics Education, 2014.

[34] J. Martyn et al., "Nurse education today exploring the relationships between teaching, approaches to learning and critical thinking in a problem-based learning foundation nursing course," Nurse Education Today, vol. 34, no. 5, pp. 829-835, 2014.

[35] R. Phungsuk et al., "Development of a problem-based learning model via a virtual learning environment," Kasetsart Journal of Social Sciences, vol. 38, no. 3, pp. 297-306, 2017.

[36] J. H. Chang et al., "A sharing mind map-oriented approach to enhance collaborative mobile learning with digital archiving systems," International Review of Research in Open and Distributed Learning, vol. 19 , no. $1,2018$.

[37] R. Hanewald, "Cultivating lifelong learning skills in undergraduate students through the collaborative creation of digital knowledge maps," Procedia - Social and Behavioral Sciences, vol. 69, pp. 847-853, 2012.

[38] A. Buran and A. Filyukov, "Mind mapping technique in language learning," Procedia - Social and Behavioral Sciences, vol. 206, pp. 215-218, 2015.

[39] M. Slifka, "Using mind mapping to influence creativity and innovation," Institute of Technology, 2012.

[40] A. H. Johnstone and K. H. Otis, "Concept mapping in problem based learning: A cautionary tale Concept mapping in problem based learning: A cautionary tale," Chemistry Education Research and Practice, vol. 7, no. 2, pp. 84-95, 2006

[41] S. Ravindranath et al., "Student's perception of mind mapping in Problem-based learning," Journal of Contemporary Med Ical Education, vol. 4, no. 2, pp. 60-66, 2016.

[42] M. J. Liyaghatdar et al., "Comparison of the effect of teaching method teaching methods lecture and group discussion on academic achievement and communication skills of students," J Res Plan Higher Educ, vol. 10, pp. 29-55, 2004

[43] S. M. Tabatabaee et al., "The impacts of individual and collaborative learning of worked out examples on problem-solving transference and cognitive load," Advances in Applied Science Research, vol. 4, no. 6, pp. 219-224, 2013.

[44] L. Greenstein, Assesing 21st Century Skillss: A Guide to Evaluating Mastery and Authentic Learning, United Kingdom: Sage Publication Ltd, 2012.

[45] B. Staniforth, "Communication skillss in social work," International Encyclopedia of the Social \& Behavioral Sciences, no. 4, pp. 284-290, 2015.

[46] J. E. Brindley et al., "Creating effective collaborative learning groups in an online environment," International Review of Research in Open and Distance Learning, vol. 10, no. 3, pp. 1-18, 2009. 
[47] J. Politis and D. Politis, "The relationship between an online synchronous learning environment and knowledge acquisition skills and traits: The blackboard collaborate experience," The Electronic Journal of e-Learning, vol. 14, no. 3, pp. 204-222, 2016.

[48] E. H. Eshuis et al., "Improving the quality of vocational students' collaboration and knowledge acquisition through instruction and joint reflection," International Journal of Computer-Supported Collaborative Learning, vol. 14, pp. 53-76, 2019.

[49] J. Dehler et al., "Guiding knowledge communication in CSCL via group knowledge awareness," Computers in Human Behavior, vol. 27, no. 3, pp. 1068-1078, 2011.

[50] O. Noroozi et al., "Facilitating learning in multidisciplinary groups with transactive CSCL scripts," International Journal of Computer Supported Collaborative Learning, vol. 8, no. 2, pp. 189-223, 2013.

[51] C. Wecker and F. Fischer, "Where is the evidence? A metaanalysis on the role of argumentation for the acquisition of domainspecific knowledge in computer-supported collaborative learning," Computers \& Education, vol. 75, pp. 218-228, 2014.

[52] A. Burke, "Group work: How to use groups effectively," The Journal of Effective Teaching, vol. 11, no. 2, pp. 87-95, 2011.

[53] L. M. Fawcett and A. F. Garton, "The effect of peer collaboration on children's problem-solving ability," British Journal of Educational Psychology, vol. 75, no. 2, pp. 157-169, 2005.

[54] C. Phielix et al., "Group awareness of social and cognitive performance in a CSCL environment: Effects of a peer feedback and reflection tool," Computers in Human Behavior, vol. 27, no. 3, pp. 1087-1102, 2011.

[55] J. Y. Park and J. B. Son, "Expression and connection: the integration of the reflective learning process and the writing process into social network sites," Journal of Online Learning and Teaching, vol. 7, no. 1, pp. 170-178, 2011.

Copyright $\odot 2020$ by the authors. This is an open access article distributed under the Creative Commons Attribution License which permits unrestricted use, distribution, and reproduction in any medium, provided the original work is properly cited (CC BY 4.0).

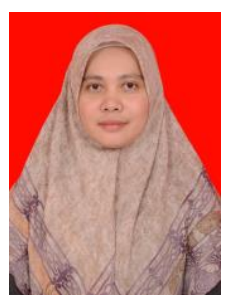

Nurkhairo Hidayati was born in Bangkinang, Indonesia. She received a bachelor's degree from Universitas Riau and a master degree in Biology Education Department from Universitas Negeri Malang, Indonesia. She currently works as a lecturer at Universitas Islam Riau, Indonesia with a focus on teaching and learning. Mrs. Hidayati research interests focus on how to improve learning experiences. Mainly engaged in problem based learning, critical thinking, creativity and habits of minds.

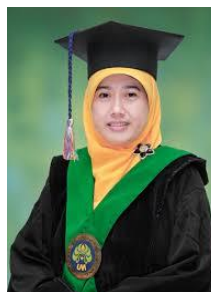

Siti Zubaidah is a professor in Genetics at Universitas Negeri Malang, Indonesia. She was born in Malang, East Java Province, Indonesia. Zubaidah completed her $\mathrm{Ph} . \mathrm{D}$. at Universitas Brawijaya and her master degree studies at Universitas Negeri Malang. Her research interests in the area of genetics, social science, teaching, and learning. She has collaborated actively with researchers in several other disciplines of education, molecular and agriculture. In terms of research, she has more than 20 Scopus publications.
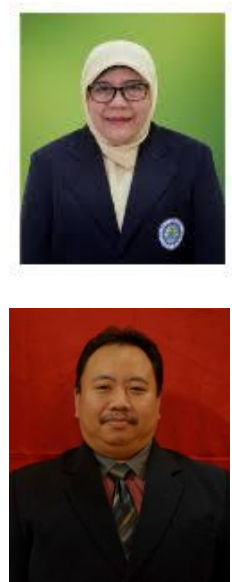

Endang Suarsini was born in April 1953. She is a doctor from Universitas Negeri Malang, Indonesia. She got the master of Basic Medical Sciences, Universitas Indonesia. Mainly engaged in microbiology, teaching, and learning research. She has participated in many national and international conferences. The results of her research have also been published in reputable journal.

Henry Praherdhino was born in January 1977. He is a lecturer in the educational technology department of Universitas Negeri Malang. He received a bachelor's degree from Universitas Airlangga, Indonesia. He holds a magister of education from Universitas Negeri Malang. Dr. Praherdhiono interests in the area of educational technology. He has several articles in reputable journals according to his area of expertise. 